第64回日本内科学会講演会（1967年）

\title{
シンポジウム 呼吸困難
}

\section{（4）呼吸困難ट換気障害}

$\begin{array}{llll}\text { 東北大学教授 } & \text { 中 } & \text { 村 } & \text { 隆 } \\ & \text { 滰 } & \text { 島 } & \text { 任 }\end{array}$

\section{SYMPOSIUM ON DYSPNEA}

\section{4) DYSPNEA AND VENTILATORY IMPAIRMENT \\ Takashi Nakamura and Tamotsu Takishima \\ Tohoku University School of Medicine}

\section{1. いとぐち}

心肺疾患患者が呼吸困難を訴点る場合，その原 因を換気障害に求めようとする試みは古くから行 なわれる。わたくしどもが98例の重症難治肺結核 患者, 40例の慢性肺気腫に和いて 1 秒量と呼吸困 難のHugh-Jonesによる分類（度）との関係をみ た成績からも，閉塞性，拘束性いずれの障害に执 いても，呼吸困難高度になると 1 秒量もほぼこれ に逆比例して減少することが知られた。

\section{2. 压量図からみたLength-Tension不均衡説}

しかし呼吸困難を論ずる場合換気反応だけでは 不充分で，生体が換気に要するエネルギーと対比 する必要がある．このエネルギーを今Tensionと して表現すると、これには現在測定可能なるのと して胸腔内王，呼吸笳の酸素消費量，並びに呼吸 筋の活動電位があげられ，これらとLengthとして の容積変化すなわら一換量或は分時換気量との対 比が考党られる。この対比する方法に現在二つの 見解があり，両者の積によつて表わそらとする换 気仕事量説 (Christieら) と, 両者の商によつて 表わすがよいとするLength-Tension不均衡説 (Campbellら) とである.

Campbellらは仕事量説によつては不合理であ る三つの条件が説明されらるとしてLength-Ten- sion不均衡説を提唱し, 今日最す魅力むる説と考 えられているので，わたくしどすは圧量図からま ずこの点に関し検討を加えた。

はじめにTensionを胸腔内圧（=食道内圧）, Lengthを量とみなして，圧量図から仕事量説と L-T不均衡説との関係をみると，理論的に粘性抵 抗增加時と弾性抵抗增加時とでは，王量図は明ら かに異なるが，換気仕事量の增加する様式にはほ とんど差が認められないしかし不均衡説からみ ると, 粘性抵抗增加之弾性抵抗增加の差は明らか. であつて, 粘性増加では吸気初期不均衡が著しく そも吸気の終りには正常にもどるのに反し, 弾性 負荷では吸気中一定で変らない

この点不均衡説に長所が認められるが，実際の 閉塞性, 拘束性肺疾患ではどうであるらか 又安 静時には呼吸困難なく，運動時にの及呼吸困難を 訴党る拘束性障害患者で閉塞性障害が全くみられ， ない場合，この呼吸困難をL-T不均衡説によつて 説明するとすれば，運動時L/T関係の悪化を如何 に考党るべきかについて検討を加えた。

方法は 300 2,000 ccの死腔負荷過剩換気実験 によつた。健康者においては換気量 $37 / \mathrm{min}$ に增 加し, 換気仕事量 $7 \mathrm{~kg} \mathrm{M} / \mathrm{min}$ 之著堌しても壬/量 比は $30 \mathrm{cmH}_{2} \mathrm{O} / L$ を越えず著しく低值を示した。 
慢性肺気腫においては過剩換気時吸気初期に 圧/量比は $200 \mathrm{cmH}_{2} \mathrm{O} / L$ を越え，著しい增加が 認められたが，先に示した理論的考察と異なり特 に注目されるのは，吸気終期に圧/量比が低下せ ず，過剩換気に伴なつて漸次增加することで，こ の理由としては本症の如く肺内機械的時定数不均 等分布があると動肺コムプライアンスが換気数増 加に伴なつて低下寸ることが実際の成績から確か められた。すなわち閉塞性障害に颃いてる圧/量 比の悪化は単に粘性抵抗增加のみならず弾性抵抗 增加によつてる招来されることが明らかにされ た。尚肺気腫患者は機残量が著增する為, 胸郭の 静コムプライアンス曲線の上部でコムプライアン スの低い部分を換気に使用することも弾性抵抗増 加を促進する重要な因子と考学られた。

次に拘束性肺疾患に招いては，压/量比方吸気 中ひとしく增加するばかりでなく，先に示した理 論上異なり，吸気初期に粘性抵抗による土/量比 の重化が注目され，この点拘束性障害といえどる その王/量関係の悪化には粘性抵抗の関与が無視 しえない.わたくしどもが重症難治肺結核につい て克た成績でも，呼吸困難高度例は動肺コムプラ イアンス低下のみならず肺粘性抵抗增加が著明で あつた。な和吸気終期（吸気位）に和ける王/量比 が換気量增加に伴なつて上昇する現象がみられ， この理由として本症の静肺コムプライアンス曲線 が吸気位に特いて直線でなく曲線となることが知 られた。

以上飞よつて運動時圧/量比が上暴する原因と しては，閉塞性，拘束性疾患のいずれをとわず粘 性抵抗增加, 弾性抵抗増加両者の関与が重要であ ることが明示された。

次に呼吸困難の程度と圧/量比との関係をる る ベく，吸気はじめから0.2l吸気位における生/量 比が换気量增加に伴ない変化する様式を健康者,

肺線維症，肺気腫の典型例で追究した（図 1). $0.2 l$ 位をとつたのは吸気初期では圧量図上での 変化が急峻で測定誤差を伴ないやすいと考えた故 である。

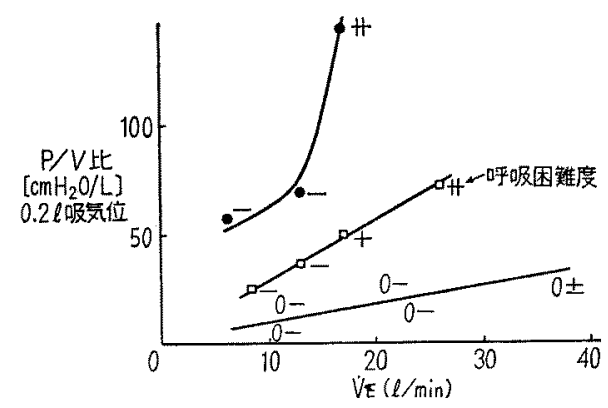

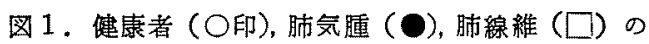
各代表例，吸気 $0.2 l$ 位に打ける眴腔内仕 (胸腔内无一安踏呼気位胸腔内正十胸郭の取

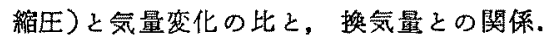

本成績からみると，いずれる換気增大に伴ない 圧/量比の増加をみ、ことに肺気腫に执いて著し いが，拘束性障害患者に乱いても増加すること は，本症の運動時呼吸困難をL-T不均衡説か，ら説 明するのに好都合である。しかし疾患によつて圧 /量比が異なり，閉塞性障害例では圧量/比が著し く高値をとらないと呼吸困難を感じがたいのに， 拘束性障害例ではかなり低値で著しい呼吸困難を 訴壳る。

このことから，呼吸困難にL-T不均衡が関与す るとしても，L-Tすなわら圧/量関係の瞬時的上 昇ではなく，その持続性が問題となると思われ る.

\section{3. 換気仕事量の再検討}

この意味に牤いて，L-T不均衡説から換気仕事 量を再検討する必要がある。すなわら換気仕事量 は積分量であるため，これを瞬時的圧変化の代り にTensionとして用いらるや否やの問題である.

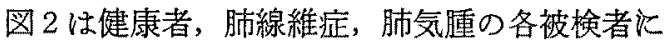
死空換気を行なわしめ，肺胞 $\mathrm{CO}_{2}$ 分王を上昇せし めた際の過剩換気に要する換気仕事量と換気量と の関係を示す 本図から，疾患肺では健康者に比 乙同一換気量に要する換気仕事量が著しく大なる ことが知られるが，ことに慢性肺気腫患者では換 気量がある一定值（これは多分M B C K相当する と思われる）に近づくと仕事量が急激に上昇する のがみられる。 


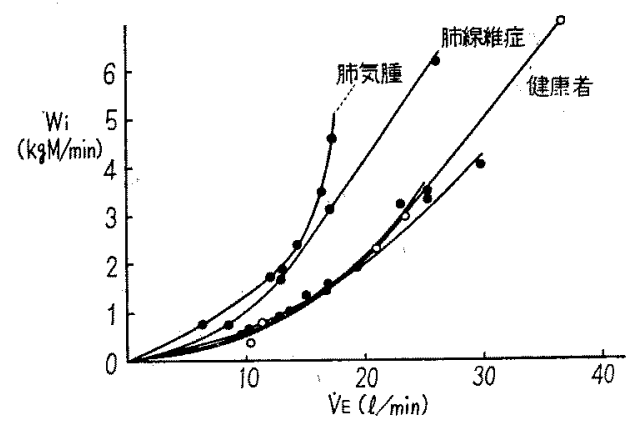

図2、吸気時换気仕事量亡换気量との関係.

しかし本図から換気仕事量絶体值のみをとり呼 吸困難と対比すると，健康者では呼吸困難感なく とむ呼吸困難を訴える肺気腫患者之同程度に換気 仕事量が增加しらるから，呼吸困難とはほとんど みるべき相関を示さない

一方前述の如く，換気仕事量を肺に加わるTensionの程度を表わす指数と考克，これとLengthに 相当する換気量との関係からL-T関係を求め呼吸 困難を評価すると，かなりよい相関が党られた。 しかし呼吸困難が全くない群と高度群の間に一線 を画し難く，先の圧/量比には明らかに勝るが， 換気仕事量のみでる不充分である。

\section{4. 呼吸筋の換気効率}

これまでは換気仕事量を肺に加わるTension 考えてきたが，これには問題があり，呼吸筋のエ ネルギー効率を考える必要がある。すなわら呼吸 器に加わるTensionは呼吸中权から延䯣の運動神 経ニューロンプールを経て呼吸筋に伝達されるイ ンパルスである。これが哦吸筋に入り，運動のエ ネルギーに変換されて胸郭に伝わり，その結果之 して換気仕事がなされるので, たと光呼吸筋自体 のエネルギー効率が等しいとしても，これが胸郭 を動かす際, 胸郭系の粘弾性或いは構造上の变化 から，何らか非湶型の能率低下が起こる可能性が 西るとすれば，先に示した換気仕事量をTension とみなすことはあやまりであり，その先の呼吸 矨が発生するエネルギー”をTensionとしてとら えなければならないこの点わたくしどもは呼吸 筋のエネルギーを呼吸筋の酸素消費量によつて表 わしらると考克た。

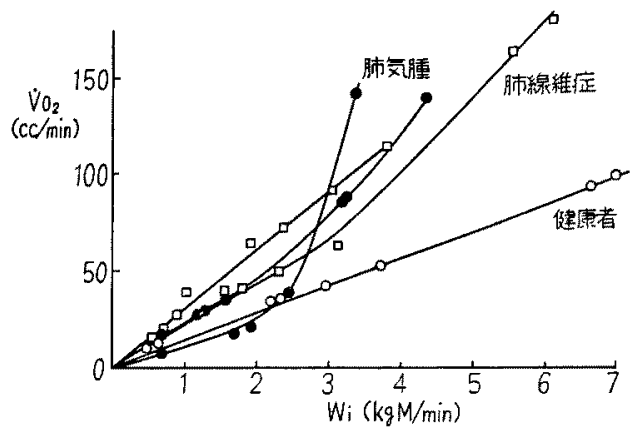

図 3. 呼吸的の酸素消費量 $\left(\mathrm{VO}_{2}\right)$ と吸気時换気仕

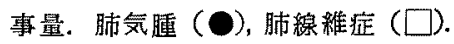

図 3 は健康者, 肺気腫, 肺線維症の各被検者に 死腔換気による過剩換気を起こさせた際, 吸気時 換気仕事量と呼吸筋の换気に要した酸素消費量と の関係を示すが，健康者においては他に比してエ. ネルギー効率がよく，乙か子換気量 $36 l / \mathrm{min}$ ，換 気仕事量 $7 \mathrm{kgM} / \mathrm{min}$ 達する過剩換気においても 効率は全く低下しないことが知られる。

しかるに疾患肺ことに肺気腫の 1 例では, 換気 仕事量 $2 \mathrm{kgM} / \mathrm{min}$ 越える頃から酸素消費量急激 増加し，著しい効率低下をみる．換気仕事量を エネルギー換算し，酸素消費量とから換気の機械 的効率を求めると，健康者は $3.6 \%$ で一定であ るのに, 肺線維症では安静換気時 $2.7 \%$ とすでに 低下を示し，26l/minの過剩換気時 $1.5 \%$ を゙低 下, 肺気腫例では安静換気時 $4.5 \%$ でむしろ高值 をとり，10l/min以上の換気量增加では急激に低 下して1\%以下に悪化をみる。

以上によつてTensionと乙て換気仕事量を用い ることには，明らかに限度のあることが知られた。

\section{5. 呼吸筋酸素消費量/換気量比亡呼吸困難}

図 4 は過剩換気時つ呼吸筋の換気に要する酸素 消費量と換気量との関係を, 健康者, 肺気腫, 肺 線維症患者についてみたるので西る，健康者に比 し疾患肺に打いては呼吸筋の酸素消費量が著しく 高く，ことに換気量が $20 l / \mathrm{min}$ 附近で急激に增加 することが知られる。しかし酸素消費量絶体値の みによつて呼吸困難を評価することは，健康者に 抒いて呼吸困難なくとも酸素消費量著增しらるこ とから，不可能である. 


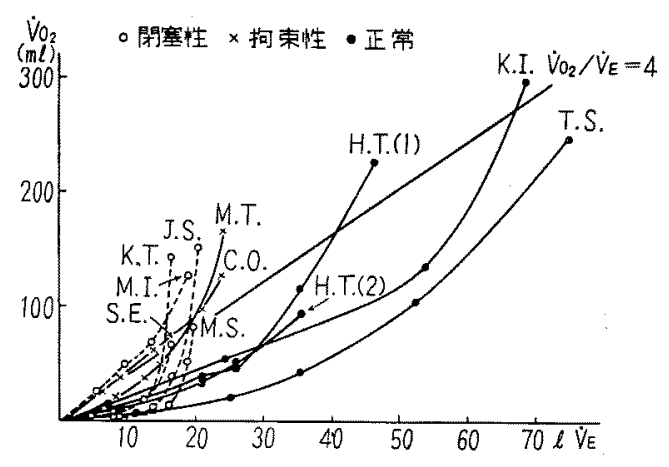

図 4.呼吸筋 $\mathrm{O}_{2}$ 消費量と換気仕事量との関係。健 康者 (○), 肺気腫 (O), 肺線維症 $(x)$. 各症 例の多くは $\dot{V O}_{2} / \dot{V E}$ 比が 4 を越方ると呼吸困 難が明らかとなる。

したがつて呼吸筋の酸素消費量をTension と考 光，换気量との対比において呼吸困難を評価する と，換気仕事量を用いる場合より中枢側に括いて Tensionを把えらるという点で明らか勝れた方 法といいるる。

図 4 に打いて健康者, 疾患肺をとわず，お〉よ そ呼吸筋 $\mathrm{O}_{2}$ 消費費量/換気量比が 4 を越えると呼 吸困難が著しくなる傾向がみられた，又安静換気 時すでにこの比が 4 を越壳ているるのは安静时す でに軽度の呼吸困難を訴える症例であり，しえが つてこの比と呼吸困難とには明らかな相関がみら 机た。

以上によつて呼吸筋の酸素消費量の測定は肺胸 郭系に加わる神経系インパルスの量的把握として 極めて重要な方法であり，又Length-Tension関係 のTensionとしても勝れた指標といらことができ る.

\section{6. 運動時呼吸困難にかんする一考察}

先に呼吸筋の酸素消費量/換気量比が 4 を越兄 ると呼吸困難が著明になることを示したが，しか らば運動時呼吸困難は如何なる機構で発生し，如 何なる過程を経て $\mathrm{O}_{2}$ (呼吸筋) $/ \dot{\mathrm{V}} \mathrm{E} か ゙ 4$ を越す ようになるのか問題である。

この点わたくしどもは次の如く考えている．す なわら運動負荷時呼吸中枢から出されるventilation demandは, 肺胸郭系のインピーダンス増加 によつて遂行されえず, muscle spindleのサーボ 機構によつて漸次Tension增加が起こり，その要
求が満たされるようになるが，初めのヴ demand では換気血流比の悪化に基づくアノキシア，ハイ パーカプニアを代償しえず，その為呼吸中枢はさ らに新たな $\dot{E}$ demandを指令し，次いでそれを達 成すべくTensionが増加していく，これが $\dot{V}_{2} / \dot{V}_{\mathbf{E}}$ $=4$ を越す程Tensionが増加した時呼吸困難を発 生する。

もちろん以上法L-T不均衡説からみた呼吸困難 発生機序であつて, 従来呼吸困難発生に重要視さ れている他の諸因子の存在を否定するものでない ことはいらをまたない。

\section{7. 胸壁運動と腹壁運動}

わたくしどもは磁場变化によつて容積変化を測 定する方法として，電磁呼吸計を試作した，本計 によつて換気運動のらち何\%が胸郭の運動により もたらされ，何\%が横隔膜したがつて腹壁の運動 により行なわれるかを明らかにすることが可能で ある。

健康者に打いては安静換気, 運動時, 肺活量測 定時, ティフノー検查時全てにわたり，胸壁と腹 壁運動は注ぼ同位相であり，ただ被検者により両 者の比率に差をみるのみであるのに，肺気腫患者 では最大換気時胸壁腹壁両運動間に全く位相を異 にしたparadoxycalな動きがみられ，又運動時に おいても異常な型が検出された，かかる胸腹壁間 にみられる換気運動協調の破綻は, 先に述べた本 症にみられる過剩換気時換気効率の低下，呼吸筋 酸素消費量増加の重要な因子と考光られ, 呼吸困 難発生に大きな役割を演ずると想像された。

\section{8. まとめ}

Length-Tension不均衡説の立場から，Tension として胸腙内圧, 換気仕事量, 呼吸筋の酸素消費 量を測定，換気量との対比において呼吸困難との 関㐿を考察した，瞬間的胸腔内压の変化は呼吸困 難を関係少なく，又換気効率の低下が著しい場合 換気仕事量もTensionを表わす指数とはなり難 い. 一方呼吸筋 $\mathrm{O}_{2}$ 消費量は呼吸中枢よりのインパ ルスを忠実に反映し，Tensionを表わす良き指標 となりえここと換気量との比は呼吸困難とよく 相関をみた。ことにこの比が $4 \mathrm{cc} /$ /をこえると呼 吸困難が明らかに増強することが確認された。 